\title{
Research Paper: \\ Health Risk Assessment of Liza Parsia Fish Lipids: Heavy Metals and DDTs Contaminations
}

\author{
Md. Abu Rayhan Khan' ${ }^{1}$, Muhammad Shamim Al Mamun ${ }^{1 *}$ iD, Mosummath Hosna Ara ${ }^{1}$ iD
}

1. Department of Chemistry Discipline, School of Science, Engineering and Technology, Khulna University, Khulna, Bangladesh.

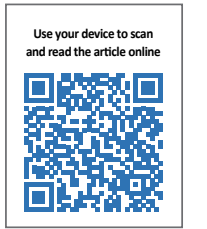

How to cite this paper Rayhan Khan MA, Al Mamun MS, Hosna Ara M. Health Risk Assessment of Liza Parsia Fish Lipids: Heavy Metals and DDTs Contaminations. Iranian Journal of Toxicology. 2021; 15(3):195-204. http://dx.doi.org/10.32598/ ijt.15.3.805.1

doi)http://dx.doi.org/10.32598/ijt.15.3.805.1

\section{(c) (1) (8)}

Article info:

Received: 03 Mar 2021

Accepted: 25 May 2021

Online Published: 01 Jul 2021

"Corresponding author:

Muhammad Shamim Al Mamun, MSc. Address: Department of Chemistry Discipline, School of Science, Engineering and Technology, Khulna University, Khulna, Bangladesh.

E-mail:smamun45@gmail.com

\section{ABSTRACT}

Background: Fish is a source of nutrition; however, toxic substances and heavy metals may enter human body due to consuming contaminated fish. The aim of this study was to investigate the levels of heavy metals and DDTs in Liza parsia, a fish species, and assess the health risk of the contaminants in the fish samples.

Methods: The extracted fish lipid was added with n-hexane and $\mathrm{H}_{2} \mathrm{SO}_{4}$ and was kept for long time. The upper organic part was collected for the analysis of DDTs by gas chromatography equipped with electron capture detector. The fish samples were homogenized by wet digestion method, and the heavy metal contents were analyzed, using an atomic absorption spectrophotometer. The health risks of the fish samples were assessed based on target hazard quotient and target cancer risk.

Results: The pesticide contents ofDDT, DDD, DDE and DDTs in the fish samples were 0.0414 , $0.000253,0.015$ and $0.0567 \mathrm{ng} / \mathrm{g}$, respectively. Also, the mean concentrations of $\mathrm{Mn}, \mathrm{Fe}, \mathrm{Cu}$ and $\mathrm{Zn}$ were $35.42 \pm 10.05,318.75 \pm 242.45,41.67 \pm 4.78$ and $281.25 \pm 5.42 \mathrm{mg} / \mathrm{kg}$, respectively. Of note, the $\mathrm{Cd}$ and $\mathrm{Pb}$ contents were below the detection limits. The concentrations of other heavy metals were above the reference limits, which can cause various disease processes.

Conclusion: The contents of four heavy metals and DDTs in the samples were above the limits. The main sources of these substances are likely due to human anthropogenic activities. Fish and other edible aquatic animals should be monitored regularly and the heavy metal levels be determined and declared to the public.

Keywords: DDTs, Heavy metals, Health risks, Pesticides, Toxicity

\section{Introduction}

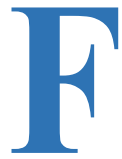

ish is an excellent food and a vital source of protein, minerals, vitamins, and fatty acids [1]. Generally, these essential ingredients are present in 442 marine species and 266 fish species caught locally in Bangladesh. Among these species, Liza parsia has gained much popularity among the local people due to its taste and nutritional value. This species lives in slightly salty (brackish) water and is mainly found in the tropical and subtropical areas [2]. Beside the food ingredients, this fish may also contain toxic substances, such as pesticides (DDTs) and heavy metals. They are considered toxic pollutants, which can accumulate in both land and sea animals, and last long in nature. Although the use of DDTs has already been banned in many parts of the world, the developing countries are still using the pesticides for agricultural and various other purposes [3]. The concerned authorities in Bangladesh have restricted 
the applications of DDTs but there is no systematic plan for monitoring its spread in the environment. Consequently, they are still detectible in aquatic as well as terrestrial ecosystems [4]. In aquatic environment, DDTs are transferred from water to fish and eventually enter the human body [3].

A study has shown that fish contributes only $10 \%$ to human diet whereas $90 \%$ of DDTs in the human body is due to consumption of animal fat including fish species [5]. The exposure of human body to DDTs can cause severe health risks, such as impaired immune system, disrupted thyroid function and other hormones, lower fertility, diabetes, and various cancers (pancreas, breast, and liver) [5]. Similar to DDTs, heavy metals, with specific densities more than $5 \mathrm{~g}$ / $\mathrm{cm}^{3}$, are also toxic pollutants in human diet [6]. The heavy metals are originated in water from natural sources and human anthropogenic activities, such as mining, transportation, industrial and household wastes. In addition, application of wastewater and agrochemical compounds, such as fertilizers, pesticides, and insecticides from farmlands are the other popular sources of these pollutants [7]. When fish are cultivated in polluted waters, heavy metals accumulate in them and eventually enter the human food chain [8]. Heavy metals bind to nucleic acids, proteins, enzymes, and bio-membranes in human cells [9]. While some metal ions are biologically useful at low concentration, such as $\mathrm{Mn}, \mathrm{Fe}$, $\mathrm{Cu}$ and $\mathrm{Zn}$ but cadmium and lead have no useful biological benefit to human cells and tissues. These heavy metals are toxic at any concentration and their acute exposure has detrimental effects on both human and animal health [10]. For instance, the elevated level of iron can lead to high hemoglobin level, which may cause liver cancer and/or diabetes. Also, it retards the cognitive and intellectual development in children. Cadmium has fatal effects on human health, causing bone and kidney impairment, hepatic dysfunction, and certain physiological disorders. The excessive level of lead in foods reduces mental performance in children and cause hypertension in adults $[11,12]$.

This study investigated the pesticide contents of Liza parsia by a Gas Chromatography (GC) unit, equipped with Eectron Capture Detector (ECD). Our findings revealed that DDTs were present in fish samples, likely because they were used as pesticides, despite being banned by the governmental policies in Bangladesh. This study further estimated the concentrations of various metals, such as $\mathrm{Mn}$, $\mathrm{Fe}, \mathrm{Cu}, \mathrm{Zn}, \mathrm{Pb}$, and $\mathrm{Cd}$ by Atomic Absorption Spectroscopy (AAS). The concentrations of heavy metals exceeded the allowable limits in several cases. Based on our findings, we are concerned about the transfer and accumulation of heavy metals and DDTs in the human body through the consumption of contaminated fish, which may lead to carcinogenic and pathologic conditions in humans. Finally, this study as- sessed the various health risk indices for the heavy metals and DDTs in Liza parsia fish.

\section{Materials and Methods}

Geographic area: Mohesshorkati is an area of Assasuni Upozilla under Satkhira district in the southern part of Bangladesh as shown in Figure 1. The area of Mohesshorkati is $402.36 \mathrm{Km}^{2}$ and is located between $21^{\circ} 36^{\prime}$ and $22^{\circ} 54^{\prime}$ north latitudes and between $88^{\circ} 54^{\prime}$ and $89^{\circ} 20^{\prime}$ east longitudes. It is surrounded by Tala, Satkhira sadar and Debhata Upazila on the north, Debhata and Kaligonj Upazila on the west, Shyamnagar Upazila on the south, and Khulna District on the east side of the country.

Analysis of moisture: A fixed amount of the fish samples were dried at $105^{\circ} \mathrm{C}$ in an oven for 10 hours and the moisture percentage was calculated by comparing the weight before and after drying [13].

Analysis of ash: A set portion of fish samples were burned in a muffle furnace at $550-600^{\circ} \mathrm{C}$ and the ash was quantified as the percentage of the fish [13].

Analysis of lipid: After evaporating the moisture, the samples were finely ground, and the lipid was extracted, using ethyl ether solvent. The solvent was then evaporated by heating and the percentage of the lipid content was determined [13].

Analysis of protein: The percentage of protein contents in Liza parsia samples were estimated by micro-kjeldahl method [13].

Analysis of DDTs: The fish lipid was dissolved in nhexane to which concentrated $\mathrm{H}_{2} \mathrm{SO}_{4}$ was added. The upper layer was aspirated and analyzed in GC-ECD for quantification of DDTs [4].

Analysis of heavy metals: Tri-acid mixture (5:1:1; 70\% $\mathrm{HNO}_{3}, 70 \% \mathrm{H}_{2} \mathrm{SO}_{4}$, and $65 \% \mathrm{HClO}_{4}$ ) was added with a set portion of the fish samples. Then, the solution was digested at $80^{\circ} \mathrm{C}$ for 30 minutes and analyzed on an AAS unit (Shimadzu model AA-7000) for the estimation of heavy metal contents ( $\mathrm{Mn}, \mathrm{Fe}, \mathrm{Cu}, \mathrm{Zn}, \mathrm{Pb}$, and $\mathrm{Cd}$ ) [14].

Metal Pollution Index (MPI): Metal pollution index was used to assess the contamination of heavy metals for each of the fish samples as Formula 1:

$$
\text { 1. } M P I=\left(C M_{1} \times C M_{2} \times C M 3 \times \ldots \times C M_{n}\right)^{1 / n}
$$




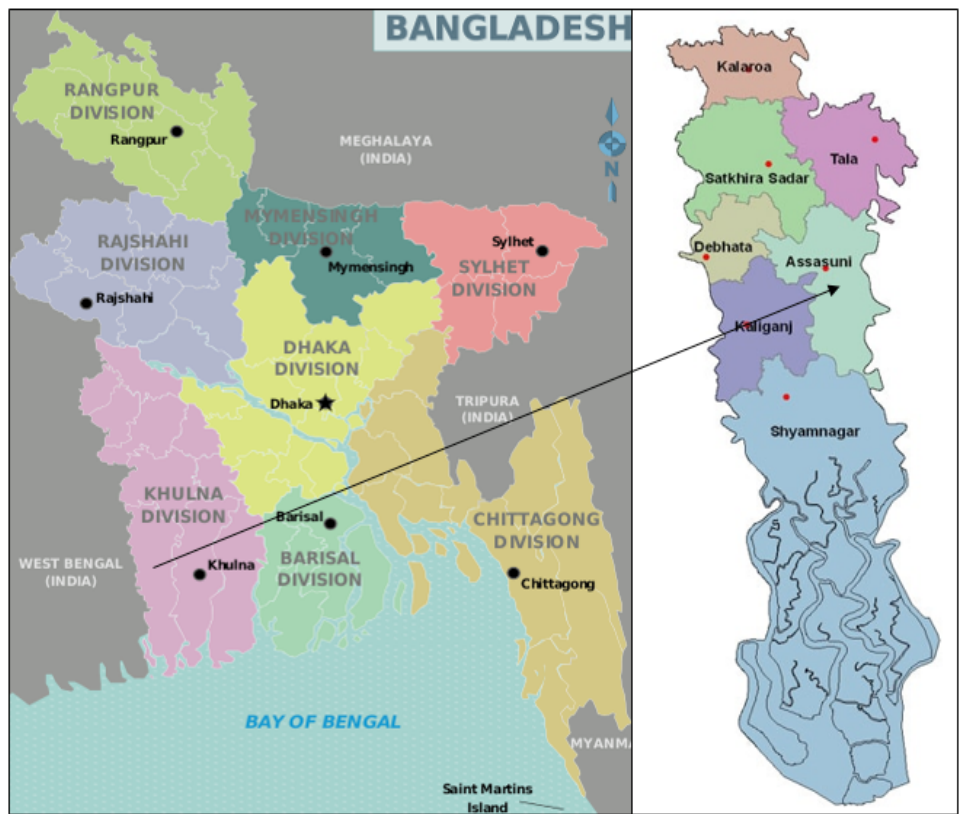

Figure 1. The geographic map of the study area (Mohesshorkati, Assasuni, Satkhira)

Where, $\mathrm{CM}_{1}$ is the concentration of first heavy metal; $\mathrm{CM}_{\mathrm{n}}$ is the concentration of " $\mathrm{nth}$ " heavy metal (mg/ $\mathrm{kg}$ of dry weight) in the fish samples. If MPI was greater than one, it indicated the existence of contamination. The $\mathrm{MPI}<1$ indicated no contamination [15].

Health risk assessment: The carcinogenic and noncarcinogenic conditions due to heavy metals were assessed by the following health risk model.

Estimated Daily Intake (EDI): The estimated daily intake value was calculated, using the Formula 2:

$$
\text { 2. } E D I=\frac{C_{m} \times I_{g} \times C_{f}}{W b}
$$

Where, $\mathrm{C}_{\mathrm{m}}$ is the concentration of heavy metals in the fish samples ( $\mathrm{mg} / \mathrm{kg}$ of dry weight); $\mathrm{I}_{\mathrm{g}}$ is the consumption rate of fish for Bangladeshi people (62.58 g/day); $\mathrm{W}_{\mathrm{b}}$ is the average body weight of Bangladeshi people (49.5 $\mathrm{kg})$, and $\mathrm{Cf}$ is the conversion factor $(0.3227)[16,17]$.

Target hazard quotient for heavy metals: The Target Hazard Quotient (THQ) was evaluated, using the Formula 3:

$$
\text { 3. } T H Q=\frac{C_{m} \times I_{g} \times E_{f} \times D_{e} \times C_{f}}{D_{f} \times W_{b} \times T_{\text {avncar }}}
$$

Where, $\mathrm{E}_{\mathrm{f}}$ is the exposure frequency and is equal to 365 days/year. $\mathrm{D}_{\mathrm{e}}$ is the exposure duration (71.8 years). $\mathrm{D}_{\mathrm{f}}$ is the reference dose of $\mathrm{Mn}, \mathrm{Fe}, \mathrm{Cu}, \mathrm{Zn}, \mathrm{Cd}$ and $\mathrm{Pb}$ that has been considered as $0.14,0.7,0.037,0.30,0.0005$ and $0.0036 \mathrm{mg} /$ $\mathrm{kg} /$ day, respectively (Table 2 ). $\mathrm{T}_{\text {avncar }}$ indicates the average time for non-carcinogens (365 days/year $\left.\times \mathrm{D}_{\mathrm{e}}\right)$ [17].
Hazardous Index (HI): The hazard index was calculated by the Formula 4 [17]:

$$
\begin{aligned}
& \text { 4. } H I=\sum T H Q=T H Q_{M n}+T H Q_{F e}+T H Q_{C u}+T H Q_{Z n} \\
& +T H Q_{P b}+T H Q_{C d}
\end{aligned}
$$

Target cancer risk: The target cancer risk was calculated by the Formula 5:

$$
\text { 5. TCR }=\frac{C_{m} \times I_{g} \times E_{f} \times D_{e} \times S_{c p s} \times C_{f}}{D_{f} \times W_{b} \times T_{\text {avncar }}}
$$

Where, $\mathrm{S}_{\mathrm{cps}}$ is the carcinogenic potency slope. The $\mathrm{S}_{\mathrm{cp}}$ values of $\mathrm{Cd}$ and $\mathrm{Pb}$ are 6.1 and $0.0085 \mathrm{mg} / \mathrm{kg}$ body weight/day, respectively [17]. Some heavy metals like $\mathrm{Mn}, \mathrm{Fe}, \mathrm{Cu}$ and $\mathrm{Zn}$ do not have carcinogenic effects on the human body. So, the $S_{\mathrm{cps}}$ values for these heavy metals have not been established yet [18].

Health risk assessment: Exposure to pesticides, such as DDTs causes various fatal diseases in humans. The probability of causing cancer and other diseases can be evaluated by estimating the daily intake and target quotients for DDTs, leading to the determination of target cancer risk as described below.

Estimated Daily Intake (EDI): The estimated daily intake of DDTs was calculated as Formula 6.

6. $\mathrm{EDI}=\frac{C_{D} \times I_{g}}{W_{b}}$

Where, $\mathrm{C}_{\mathrm{D}}$ is the concentration of DDTs (ng/g ww), $\mathrm{I}_{\mathrm{g}}$ is the consumption rate of fish $(62.58 \mathrm{~g} /$ day $)$ and $\mathrm{W}_{\mathrm{b}}$ is 
Table 1. Concentrations of heavy metals and residual amounts of DDTs (ng/g) in Liza parsia samples

\begin{tabular}{|c|c|c|c|c|c|c|}
\hline Sample Name & $M n$ & $\mathrm{Fe}$ & $\mathrm{Cu}$ & $\mathrm{Zn}$ & Cd & $\mathrm{Pb}$ \\
\hline \multirow{3}{*}{ Liza parsia } & 31.25 & 584.38 & 37.50 & 275.00 & ND & ND \\
\hline & 28.13 & 262.50 & 46.88 & 284.38 & ND & ND \\
\hline & 46.88 & 109.38 & 40.63 & 284.38 & ND & ND \\
\hline Mean \pm SD & $35.42 \pm 10.05$ & $318.75 \pm 242.45$ & $41.67 \pm 4.78$ & $281.25 \pm 5.42$ & ND & ND \\
\hline Range & $28.13-46.88$ & $109.38-584.38$ & $37.50-46.88$ & $275.00-284.38$ & ND & ND \\
\hline Reference value & $5.40^{\mathrm{a}}$ & $10-56^{\mathrm{a}}$ & $40.00^{\mathrm{a}}$ & $50.00^{b}$ & $0.50^{\mathrm{a}}$ & $2.00^{\mathrm{a}}$ \\
\hline \multirow{2}{*}{ Liza parsia } & DDT $\left(2,4^{\prime}-\mathrm{DDT}+4,4^{\prime}-\mathrm{DDT}\right)$ & DDD & DDE & Total DDTs & Ratio of DDT/DDTs & \\
\hline & 0.0414 & 0.000253 & 0.0150 & 0.0567 & 0.7302 & \\
\hline \multirow{4}{*}{ Liza parsia } & Ash & Moisture & Protein & Lipid & & \\
\hline & 2.12 & 67.69 & 17.80 & 12.39 & & \\
\hline & 2.01 & 68.23 & 17.20 & 12.56 & & \\
\hline & 2.08 & 67.27 & 17.74 & 12.91 & & \\
\hline Mean \pm SD & $2.07 \pm 0.06$ & $67.73 \pm 0.48$ & $17.58 \pm 0.33$ & $12.62 \pm 0.27$ & & \\
\hline Range & $2.01-2.12$ & $67.27-68.23$ & $17.20-17.80$ & $12.39-12.91$ & & \\
\hline
\end{tabular}

Sources: ${ }^{a}$ [20], ' [8]; ND: Not Detected; Concentrations: mg/kg of dry weight; Amounts of DDTs: ng/g

the average body weight of Bangladeshi people (49.5 $\mathrm{kg})[16,19]$.

Target hazard quotient for DDTs: The non-carcinogenic risk due to the consumption of fish contaminated with DDTs was calculated by the Formula 7 Target Hazard Quotient (THQ):

$$
\text { 7. THQ }=\frac{R_{f} D \times W_{b}}{C_{D}}
$$

Where, $\mathrm{R}_{\mathrm{f}} \mathrm{D}$ is the reference dose for DDTs (500ng/ $\mathrm{kg}$ /day); $\mathrm{W}_{\mathrm{b}}$ is the average body weight of Bangladeshi people $(49.5 \mathrm{~kg})[5,17]$.

Target cancer risk: The Target Carcinogenic Risk (TCR) for DDTs due to the consumption of the contaminated fish was calculated by the Formula 8:

$$
\text { 8. TCR }=\frac{R_{L} \times W_{b}}{C_{D} \times O S F}
$$

Where, $\mathrm{R}_{\mathrm{L}}$ is the cancer risk level $\left(1 \times 10^{-6}\right)$; OSF is the cancer oral slope factor $\left(3.4 \times 10^{-7} \mathrm{ng} / \mathrm{kg} /\right.$ day $)$ for DDTs $[5,17]$.
Statistical analyses: The means, standard deviations, one way ANOVA and Pearson's correlations of the data were calculated, using SPSS software, version 16.

\section{Results}

Food safety has become a great challenge in developing countries due to frequent application of agricultural chemicals and dumping of waste materials in the ecosystem. To ascertain the food safety and assess both the carcinogenic and non-carcinogenic risks to human health, the concentrations of the following heavy metals, $\mathrm{Mn}, \mathrm{Fe}, \mathrm{Cu}, \mathrm{Zn}, \mathrm{Cd}$ and $\mathrm{Pb}$, and DDTs in Liza parsia were determined. The levels of $\mathrm{Mn}, \mathrm{Fe}, \mathrm{Cu}$, and $\mathrm{Zn}$ were found to be $35.42 \pm 10.05,318.75 \pm 242.45,41.67 \pm 4.78$ and $281.25 \pm 5.42 \mathrm{mg} / \mathrm{kg}$, respectively. Whereas, the concentrations of $\mathrm{Pb}$ and $\mathrm{Cd}$ were below the detection limits. In this study, the most abundant metal in the fish was Fe, with the concentration being $318.75 \pm 242.45 \mathrm{mg} / \mathrm{kg}$. The concentrations of $\mathrm{Mn}, \mathrm{Fe}, \mathrm{Cu}$ and $\mathrm{Zn}$ were above the safe limits. In decreasing order, the concentrations of these heavy metals were found as follows: $\mathrm{Fe}>\mathrm{Zn}>\mathrm{Cu}>\mathrm{Mn}$.

As shown in Figure 2, the concentration of DDT varieties (2,4'-DDT + 4,4'-DDT), DDD, DDE and DDTs were 

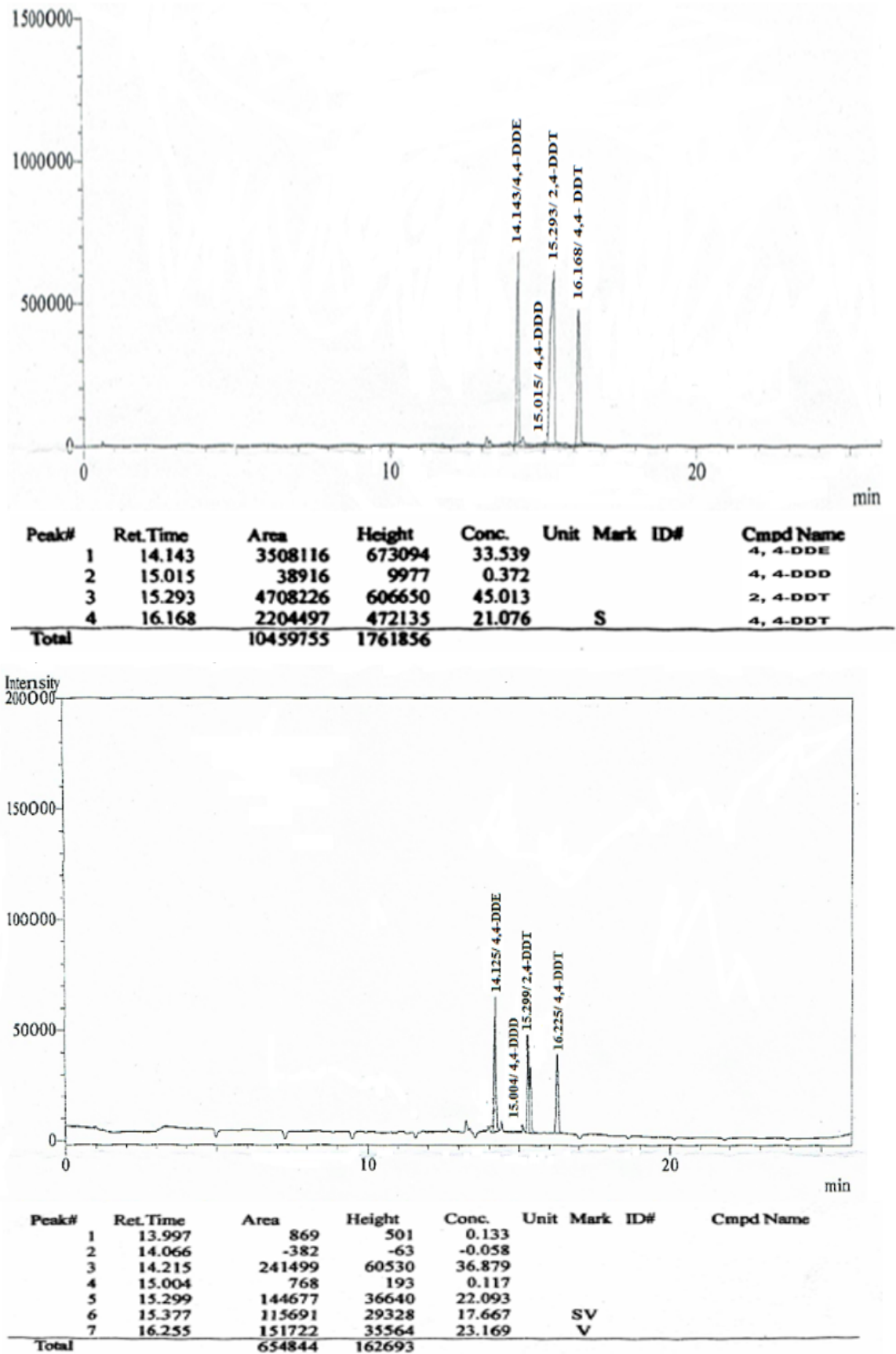

Figure 2. Gas chromatograms of (A) standard and (B) DDTs in Liza parsia samples

found to be $0.0414,0.000253,0.015$ and $0.0567 \mathrm{ng} / \mathrm{g}$, respectively. In this study, the approximate composition of Liza parsia was determined to support the level of DDTs in the fish lipid. The moisture, ash, lipid and protein contents were found to be $67.73 \pm 0.48 \%, 2.07 \pm 0.06 \%$, $17.58 \pm 0.33 \%$ and $12.62 \pm 0.27 \%$, respectively. Table 1 presents the heavy metal concentrations, DDTs and approximate composition of Liza parsia.

\section{Discussion}

Mohesshorkati area is located in the southern part of Bangladesh. Due to various anthropogenic activities, heavy metals enter waters, hence into the aquatic animals in this area. These toxic metals are transferred to human body through the consumption of foods and affect the normal functions of the various organs. Therefore, regular monitoring of heavy metals and pesticide in fish products is essential to ensure the safety and quality 
Table 2. Comparison of heavy metal concentration $(\mathrm{mg} / \mathrm{kg})$ and DDTs $(\mathrm{ng} / \mathrm{g})$ with other studies

\begin{tabular}{|c|c|c|c|c|c|c|c|c|}
\hline Country & $\mathrm{Mn}$ & $\mathrm{Fe}$ & $\mathrm{Cu}$ & $\mathrm{Zn}$ & $\mathrm{Pb}$ & $\mathrm{Cd}$ & DDTs & Ref. \\
\hline Iran & -- & 4.65 & -- & -- & -- & -- & -- & {$[1]$} \\
\hline \multirow{3}{*}{ Ethiopia } & -- & -- & 0.54 & 3.68 & 0.004 & -- & \multirow{3}{*}{10.83} & \multirow{3}{*}{ [3] } \\
\hline & -- & -- & 0.58 & 3.67 & 0.003 & -- & & \\
\hline & -- & -- & 0.65 & 5.30 & 0.003 & -- & & \\
\hline Bangladesh & -- & -- & -- & -- & -- & -- & 81.37 & [4] \\
\hline Italy & -- & -- & -- & -- & -- & -- & $\begin{array}{l}22.40 \\
3.10\end{array}$ & [5] \\
\hline \multirow{3}{*}{ Turkey } & -- & 31.08 & 4.04 & 25.45 & 49.93 & 3.44 & \multirow{3}{*}{--} & \multirow{3}{*}{ [8] } \\
\hline & -- & 18.45 & 3.66 & 24.53 & 32.80 & 2.68 & & \\
\hline & -- & 19.97 & 27.13 & 46.88 & 39.94 & 7.22 & & \\
\hline \multirow{2}{*}{ Janadeleh } & -- & -- & 0.003 & 0.01 & 0.0004 & 0.0002 & \multirow{2}{*}{--} & \multirow{2}{*}{ [10] } \\
\hline & -- & -- & 0.004 & 0.02 & 0.0007 & 0.0004 & & \\
\hline Ethiopia & -- & -- & -- & -- & -- & -- & $\begin{array}{l}2.33 \\
4.38 \\
4.55 \\
9.00\end{array}$ & [19] \\
\hline Saudi Arabia & 0.96 & 55.70 & 3.52 & -- & 1.40 & 0.16 & -- & [20] \\
\hline Bangladesh & -- & -- & 5.14 & -- & 3.79 & 0.12 & -- & [21] \\
\hline Iran & -- & -- & -- & -- & -- & -- & $\begin{array}{l}33.00 \\
31.00\end{array}$ & [29] \\
\hline South Africa & -- & -- & -- & -- & -- & -- & $645-2399$ & [30] \\
\hline Bangladesh & -- & -- & 12.10 & -- & 13.88 & 0.39 & -- & [31] \\
\hline China & -- & -- & -- & -- & -- & -- & $3.40-7.80$ & [32] \\
\hline India & -- & $185.00-215.00$ & -- & $1.40-272.20$ & $29.70-44.8$ & $0.11-0.15$ & -- & [33] \\
\hline $\begin{array}{l}\text { Bangladesh } \\
\text { Mohesshorkati }\end{array}$ & $28.13-46.88$ & $109.38-584.38$ & $37.50-46.88$ & $275.00-284.38$ & ND & $\begin{array}{l}\text { ND } \\
\text { ND }\end{array}$ & 0.0567 & $\begin{array}{l}\text { Pres- } \\
\text { ent } \\
\text { study }\end{array}$ \\
\hline
\end{tabular}

of human foods. In this study, six heavy metals were investigated and analyzed in the fish species. Among the heavy metals, $\mathrm{Mn}, \mathrm{Fe}, \mathrm{Cu}$, and $\mathrm{Zn}$ are biologically important whereas $\mathrm{Cd}$ and $\mathrm{Pb}$ are hazardous to human organs. As shown in Table 1, the levels of $\mathrm{Mn}, \mathrm{Fe}, \mathrm{Cu}$, and $\mathrm{Zn}$, except for $\mathrm{Pb}$ and $\mathrm{Cd}$, were found to be above the safe limits. These elements might have originated from various sources. For instance, the sources of $\mathrm{Mn}$ in the environment are cement materials, petroleum products and metallurgy processes. Iron, which is an essential element for the physiological functions in humans, may come from disintegrating metal parts, fertilizers, plant and animal wastes. Further, excess $\mathrm{Cu}$ and $\mathrm{Zn}$ in the environment may originate from transportation, liquid petroleum stations, battery, oil wastes, and oil leakage from boats and ships [14]. 
Metal Pollution Index (MPI): The metal pollution indices of heavy metals in Liza parsia were found as $101.49 \pm 14.80$. In this study, MPI was greater than one (MPI>1), indicating that the fish samples were contaminated with heavy metals [7]. This value also exceeded the maximum permissible limit of $3.83 \mathrm{mg} / \mathrm{kg}$. Shehawy, et al. analyzed the MPI in some aquatic species and reported that the maximum value traced in Sardinella longiceps was $1.82 \mathrm{mg} / \mathrm{kg}$ whereas the minimum value detected in Sparus aurata was $0.44 \mathrm{mg} / \mathrm{kg}$ [20]. Ahmed, et al. studied Liza parsia, in which the MPI was $3.65 \mathrm{mg} / \mathrm{kg}$ [21]. This value was much lower than that detected in the current study. Based on the results from this study, we determined that the levels of heavy metals were higher than the acceptable international limits.

Estimated Daily Intake (EDI): This study revealed that the estimated daily intake values for $\mathrm{Mn}, \mathrm{Fe}, \mathrm{Cu}$ and $\mathrm{Zn}$ were less than the corresponding reference doses $\left(D_{\mathrm{f}}\right)$ for these metals. The New York State Department of Health (NYSDOH) has suggested that if the ratio of EDI/ $D_{f}$ is $\leq 1$, its health risk is minimal. If the EDI/ $D_{f}$ ratio is 1-5 times above the $D_{f}$ it is associated with low health risks. When $\mathrm{EDI} / \mathrm{D}_{\mathrm{f}}$ ratio is greater than 5-10 above the $D_{f}$, it is associated with moderate health risks. Finally, if the EDI/ $\mathrm{D}_{\mathrm{f}}$ ratio is 10 times above the $\mathrm{D}_{\mathrm{f}}$ it is associated with high health risks [22]. Based on our results, $\mathrm{Zn}, \mathrm{Mn}$ and $\mathrm{Fe}$ posed minimum to low health risks whereas $\mathrm{Cu}$ posed high carcinogenic risk to humans.

Target Hazard Quotient (THQ): The target hazard quotient is the measure of non-carcinogenic health risks and the acceptable value is considered equal or less than one [23]. In this regard, Ambedkar, et al. have concluded that if the THQ value of individual metal exceeds its limit, it may cause serious health risks [24]. Based on our THQ measures, the $\mathrm{Mn}, \mathrm{Fe}, \mathrm{Cu}$ and $\mathrm{Zn}$ contents were at safe limits.

Furthermore, the combined impact of Hazard Index (HI) of all heavy metals was 1.13 that was higher than the acceptable limit of 1.0 in Liza parsia fish samples. Therefore, we can assume that the consumption of this fish might not be associated with carcinogenic health risk [25]. In general, the combined adverse effects may occur if more than one toxic substance are consumed by humans [26]. Moreover, the long-term exposure of humans to carcinogenic foods may lead to cancerous conditions.

Target carcinogenic risks: Some analyzed heavy metals, such as $\mathrm{Mn}, \mathrm{Fe}, \mathrm{Cu}$, and $\mathrm{Zn}$ are not carcinogenic and the level of $\mathrm{Pb}$ and $\mathrm{Cd}$ were below the detection limits. Thus, Liza parsia fish species in this area may not contribute to the carcinogenic effects in local people [18].
The TCR value for DDTs was found to be $2.6 \mathrm{E}^{3}$ that is above the safe limit $\left(10^{-4}\right)$. Therefore, the fact that the fish samples contained the detected level of DDTs contamination is a cause for human health concern.

Analysis of DDTs contents: In this study, the concentration of DDTs was higher than DDD and DDE. The DDTs might originate in the fish feeds. DDTs gradually convert to DDD and DDE over time. Moreover, the ratios of DDT/LDDTs in Liza parsia was found to be $0.7302 \mathrm{ng} / \mathrm{g}$. From these results, it might be predicted that the fish had been exposed to pesticides recently. Given that the ratio of DDT/ $/$ DDTs was greater than 0.5 , it suggests that recent biotransformation of DDT to DDD and DDE had occurred [4]. The accumulation of DDTs depends on the lipid content in the fish. The lower the content of water $(90 \%)$ in the fish, the higher are the contents of lipid and protein [27, 28]. In this species, the water content was found to be $67.73 \pm 0.48 \%$, suggesting higher percentages of protein and lipids in the fish (Table 1). DDTs are lipid-soluble organic compounds; therefore, they accumulate in species that have high lipid content [29]. Further, the lipid content in the fish may vary in different seasons, species, geographical location, age and the maturity of the species [28]. With changes in these parameters, the total lipid content also varies.

With the THQ $\leq 0.2 \mathrm{ng} / \mathrm{g}$, DDTs may cause negligible adverse effects on human health while if the THQ values exceed $0.2 \mathrm{ng} / \mathrm{g}$, the adverse effect on human health also rises [30]. Considering that the THQ values for DDT, DDD, DDE and DDTs in this study were 6.0 $\mathrm{E}^{5}, 9.8 \mathrm{E}$, 1.7E and $4.4 \mathrm{E} \mathrm{ng} / \mathrm{g}$, respectively, the adverse effects in humans may rach fatal conditions.

Lastly, both the developed and developing countries are cautious about their foods and their environment becoming polluted with toxic substances. At present, various studies are underway to monitor the sources and levels of environmental pollutants, and establish specific data bases to combat the problem. In this context, the current study has compared its findings with those of other studies conducted at various parts of the world to provide useful information on variations in the pollution status versus the safety of human food products.

\section{Conclusions}

In this study, the levels of $\mathrm{Fe}, \mathrm{Cu}$, and $\mathrm{Zn}$ were above the safe limits for humans in the Liza parsia fish samples, but the contents of $\mathrm{Cd}$ and $\mathrm{Pb}$ were acceptable. Anthropogenic activities, such as the use of pesticides, fertilizers, wastewaters in agricultural fields might be the potential 
sources of contaminations of heavy metals and DDTs. The indices of various health risks, such as EDI and THQ were assessed for heavy metals and DDTs. The TCR was also assessed for the carcinogenic effects of DDTs in the human body. These indices indicated the potential health risks in humans. The consumption of contaminated fish products is the most significant concern for carcinogenic and non-carcinogenic risks to human health. Moreover, the findings of this study may serve as effective references for future investigations on the subject. In this regard, we believe that necessary steps should be taken to raise the public awareness about heavy metals and DDTs contaminations in the aquatic species and the food products that originate from them in Bangladesh.

Limitations of the study: This study had limited laboratory resources to comprehensively evaluate the levels of all heavy metals and DDTs.

Recommendations for future research: Regular monitoring of the levels of heavy metals and pesticides is warranted in this geographic area of Bangladesh. Thus, the findings of this study may be useful as a data base for the further research.

\section{Ethical Considerations}

\section{Compliance with ethical guidelines}

The study measured the toxic substances (heavy metals and DDTs) in a fish species, and did not involve other animals or human subjects. Therefore, the ethical guidelines were not applicable to this study.

\section{Funding}

This research was funded by Research Cell, Khulna University, Khulna-9208, Bangladesh. File no-KU/Research Cell/04/2000-18.

\section{Author's contributions}

Conceptualization and supervision: Mosummath Hosna Ara and Muhammad Shamim Al Mamun; Methodology: Md. Abu Rayhan Khan; Investigation, writing review and editing: Mosummath Hosna Ara and Muhammad Shamim Al Mamun; Writing -original draft: Muhammad Shamim Al Mamun and Md. Abu Rayhan Khan; Data collection: Md. Abu Rayhan Khan; Data analysis: Muhammad Shamim Al Mamun and Md. Abu Rayhan Khan; Funding acquisition and resources: Mosummath Hosna Ara and Muhammad Shamim Al Mamun.

\section{Conflict of interest}

The authors declared no conflict of interest.

\section{Acknowledgements}

The authors would like to express their gratitude to the Department of Chemistry at Khulna University for supporting this study. They would also like to thank the Department of Chemistry, University of Dhaka, and Soil Resources Development Institute (SRDI) in Dhaka for their assistance with the quantification of DDTs and heavy metals experiments.

\section{References}

[1] Nazari Khorasgani Z, Raesi Vanani A, Khodayar MJ, Kalantari H, Mansouri F, Varnaseri G. Determination of Iron and chromium levels in canned fish produced in factories of Khuzestan province, southwest of Iran. Iran J Toxicol. 2017; 11(6):37-41. [DOI:10.29252/arakmu.11.6.37]

[2] Khan MAR, Ara MH, Mamun MSA. Fatty acid composition and chemical parameters of Liza parsia. J Basic Appl Chem. 2018; 8(3):1-8. https://www.researchgate.net/ profile/Muhammad-Mamun-2/publication/336304259 Fatty_Acid_Composition_and_Chemical_Parameters_of Liza_parsia/links/5ea7c417299bf11256159ab2/Fatty-AcidComposition-and-Chemical-Parameters-of-Liza-parsia.pdf

[3] Yohannes YB, Ikenaka Y, Nakayama SM, Saengtienchai A, Watanabe K, Ishizuka M. Organochlorine pesticides and heavy metals in fish from Lake Awassa, Ethiopia: Insights from stable isotope analysis. Chemosphere. 2013; 91(6):85763. [DOI:10.1016/j.chemosphere.2013.01.047]

[4] Shoeb M, Al Mamun MS, Noor RE, Mahmud MN, Mamun MI, Nahar N. Residual DDTs and fatty acid compositions in popular two sea fish samples. Dhaka Univ J Sci 2017; 65(1):77-80. https://www.researchgate.net/profile/ Muhammad-Mamun-2/publication/319135584_Residual_ DDTs_and_Fatty_Acid_Compositions_in_Popular_Two Sea_Fish_Samples/links/5993d364a6fdccaded1de56a/ Residual-DDTs-and-Fatty-Acid-Compositions-in-PopularTwo-Sea-Fish-Samples.pdf

[5] Quadroni S, Bettinetti R. Health risk assessment for the consumption of fresh and preserved fish (Alosa agone) from Lago di Como (Northern Italy). Environ Res. 2017; 156:571-8. [DOI:10.1016/j.envres.2017.04.018]

[6] Chaleshtori RS, Jadi Z. Fruits contaminated with lead, cadmium and nitrate are the risks to human health: A seasonal study. Iran J Toxicol. 2019; 13(4):27-32. [DOI:10.32598/ IJT.13.4.585.1]

[7] Sobhanardakani S, Jamshidi K. Assessment of metals $(\mathrm{Co}, \mathrm{Ni}$, and $\mathrm{Zn}$ ) content in the sediments of Mighan Wetland using geo-accumulation index. Iran J Toxicol. 2015 9(30):1386-90. http://ijt.arakmu.ac.ir/article-1-457-en.html 
[8] Aytekin T, Kargın D, Çoğun HY, Temiz Ö, Varkal HS, Kargin F. Accumulation and health risk assessment of heavy metals in tissues of the shrimp and fish species from the Yumurtalik coast of Iskenderun Gulf, Turkey. Heliyon. 2019; 5(8):e02131. [DOI:10.1016/j.heliyon.2019.e02131]

[9] Babandi A, Ya'u M, Muhammad Yakasai H, Shehu D, Babagana K, Ibrahim A, et al. Non-carcinogenic and carcinogenic risk potentials of metals exposure from vegetables grown in Sharada industrial area Kano, Nigeria. J Chem Health Risks. 2020; 10(1):1-15. [DOI:10.22034/ JCHR.2019.583982.1011]

[10] Janadeleh H, Kardani M. Heavy metals concentrations and human health risk assessment for three common species of fish from Karkheh river, Iran. Iran J Toxicol. 2016; 10(6):31-7. [DOI:10.29252/arakmu.10.6.31]

[11] Sulaiman MB, Asegbeloyin JN, Ihedioha J, Oyeka EE, Oji EO. Trace metals content of soil around a municipal solid waste dumpsite in Gombe, Nigeria: Assessing the ecological and human health impact. J Chem Health Risks. 2019; 9(3):173-90. [DOI:10.22034/JCHR.2019.668183]

[12] Delavar M, Abdollahi M, Navabi A, Sadeghi M, Hadavand S, Mansouri A. Evaluation and determination of toxic metals, lead and cadmium, in incoming raw milk from traditional and industrial farms to milk production factories in Arak, Iran. Iran J Toxicol. 2012; 6(17):630-4. http://ijt. arakmu.ac.ir/article-1-128-en.html

[13] Mazumder MS, Rahman MM, Ahmed AT, Begum M, Hossain MA. Proximate composition of some Small Indigenous Fish Species (SIS) in Bangladesh. Int J Sustain Crop Prod. 2008; 3(4):18-23. https://www.cabdirect.org/cabdirect/abstract/20083185044

[14] Rayhan Khan M A, Hosna Ara M, Kumar Dhar P. Assessment of heavy metals concentrations in the soil of Mongla industrial area, Bangladesh. Environ Health Eng Manag J. 2019; 6(3):191-202. [DOI:10.15171/EHEM.2019.22]

[15] Sobhan-Ardakani S, Ghoochian M. [Analysis of heavy metals in surface sediments from Agh Gel Wetland, Iran (Persian)]. Iran J Toxicol. 2016; 10(4):41-6. [DOI:10.32598/ IJT.10.4.210.10]

[16] Ministry of Fisheries and Livestock. Yearbook of fisheries statistics of Bangladesh [Internet]. 2018 [Updated 2018]. Available from: https://fisheries.portal.gov.bd/sites/default/files/files/fisheries.portal.gov.bd/page/ $4 \mathrm{cfbb3cc}$ c0c4_4f25_be21_b91f84bdc45c/Fisheries\%20Statistical\% 20 Yearboook\%202017-18.pdf

[17] Hosna Ara M, Khan AR, Uddin N, Dhar PK. Health risk assessment of heavy metals in the leafy, fruit, and root vegetables cultivated near Mongla industrial area, Bangladesh. J Hum Environ Health Promot. 2018; 4(4):144-52. [DOI:10.29252/jhehp.4.4.1]

[18] Javed M, Usmani N. Accumulation of heavy metals and human health risk assessment via the consumption of freshwater fish Mastacembelus armatus inhabiting, thermal power plant effluent loaded canal. Springerplus. 2016; 5:776. [DOI:10.1186/s40064-016-2471-3]

[19] Yohannes YB, Ikenaka Y, Saengtienchai A, Watanabe KP, Nakayama SM, Ishizuka M. Concentrations and human health risk assessment of organochlorine pesticides in edible fish species from a Rift Valley lake - Lake Zi- way, Ethiopia. Ecotoxicol Environ Saf. 2014; 106:95-101. [DOI:10.1016/j.ecoenv.2014.04.014]

[20] Shehawy SME, Alla AAG, Mutwally HMA. Proximate and elemental composition of important fish species in Makkah central fish market, Saudi Arabia. Food Nutr Sci. 2016; 7(6):429-39. [DOI:10.4236/fns.2016.76044]

[21] Ahmed AS, Rahman M, Sultana S, Babu SO, Sarker MS. Bioaccumulation and heavy metal concentration in tissues of some commercial fishes from the Meghna River Estuary in Bangladesh and human health implications. Mar Pollut Bull. 2019; 145:436-47. [DOI:10.1016/j.marpolbul.2019.06.035]

[22] Hopewell precision area contamination: Appendix CNYS DOH procedure for evaluating potential health risks for contaminants of concern. USA, New York: The US Department of Health and Human Services; 2007. https:/ / www.health.ny.gov/environmental/investigations/ hopewell/appendc.htm

[23] Ali M. Vegetables in Bangladesh: Economic and nutritional impact of new varieties and technologies. AVRDC. 2001:10018691350. https://ci.nii.ac.jp/naid/10018691350/

[24] Ambedkar G, Muniyan M. Bioaccumulation of metals in the five commercially important freshwater fishes in Vellar river, Tamil Nadu, India. Adv App Sci Res. 2011; 2(5):221-5. [Link Not Found]

[25] Farahmandkia Z, Moattar F, Zayeri F, Sekhavatjou MS, Mansouri N. Assessment of the risk of non-cancerous diseases under the exposure of heavy element in urban areas and troubleshooting pollutant sources (The case of Zanjan). J Hum Environ Health Promot. 2017; 2(3):177-85. [DOI:10.29252/jhehp.2.3.177]

[26] Li J, Huang ZY, Hu Y, Yang H. Potential risk assessment of heavy metals by consuming shellfish collected from Xiamen, China. Environ Sci Pollut Res Int. 2013; 20(5):2937-47. [DOI:10.1007/s11356-012-1207-3]

[27] Suganthi A, Venkatraman C, Chezhian Y. Proximate composition of different fish species collected from Muthupet mangroves. Int J Fish Aquat Stud. 2015; 2(6):420-3. https://www.fisheriesjournal.com/archives/2015/vol2issue6/PartF/2-6-78.pdf

[28] Jeyasanta KI, Patterson J. Nutritive evaluation of trash fishes in Tuticorin (India). WJFMS. 2014; 6(3):275-88. https:// www.cabdirect.org/cabdirect/abstract/20143301661

[29] Shokrzadeh lamuki M, Saeedi Saravi SS, Otadi N. [Evaluation of residues of D.D.T and D.D.A in fish collected from Caspian Sea, Iran (Persian)]. Iran J Toxicol. 2012; 6(18):704-8. https://www.sid.ir/en/journal/ViewPaper. aspx?id=263575

[30] Kwofie AB, Humphries MS, Pillay L. Bioaccumulation and risk assessment of organochlorine pesticides in fish from a global biodiversity hotspot: Isimangaliso Wetland Park, South Africa. Sci Total Environ. 2018; 621:273-81. [DOI:10.1016/j.scitotenv.2017.11.212]

[31] Ahmed AS, Sultana S, Habib A, Ullah H, Musa N, Hossain $\mathrm{MB}$, et al. Bioaccumulation of heavy metals in some commercially important fishes from a tropical river estuary suggests higher potential health risk in children than adults. Plos One. 2019; 14(10):e0219336. [DOI:10.1371/journal.pone.0219336] 
[32] Wang D, Yu Y, Zhang X, Zhang D, Zhang S, Wu M. Organochlorine pesticides in fish from Taihu Lake, China, and associated human health risk assessment. Ecotoxicol Environ Saf. 2013; 98:383-9. [DOI:10.1016/j.ecoenv.2013.07.012]

[33] Guhathakurta H, Kaviraj A. Heavy metal concentration in water, sediment, shrimp (Penaeus monodon) and mullet

(Liza parsia) in some brackish water ponds of Sunderban, India. Mar Pollut Bull. 2000; 40(11):914-20. [DOI:10.1016/ S0025-326X(00)00028-X] 